Research Article

\title{
Study of health seeking behavior and its determinants among attendees of urban health center, Dharavi, Mumbai, India
}

\author{
Subita P. Patil*, Satish S. Parbhankar, Seema S. Bansode-Gokhe, Pallavi S. Shelke, \\ Rakesh Darbar Singh
}

Department of Community Medicine, LTMMC, Mumbai, Maharashtra, India

Received: 18 May 2016

Accepted: 09 June 2016

*Correspondence:

Dr. Subita P. Patil,

E-mail: psubita@gmail.com

Copyright: (c) the author(s), publisher and licensee Medip Academy. This is an open-access article distributed under the terms of the Creative Commons Attribution Non-Commercial License, which permits unrestricted noncommercial use, distribution, and reproduction in any medium, provided the original work is properly cited.

\begin{abstract}
Background: Health seeking behaviour is an important factor in health management becomes relevant among underprivileged populations like urban slums, tribal populations. The objective of the study was to find out health seeking behavior and its determinants among attendees at Urban Health Center Dharavi, Mumbai.

Methods: This cross sectional study was conducted among 400 attendees of General OPD at Urban Health Center, Dharavi, Mumbai by systematic random sampling from Jan. to Aug. 2015. The predesigned, pretested semi structured questionnaire was administered among them after their valid informed consent.

Results: The mean age was $36.44\left(+/-14.10\right.$ SD) years, $>3 / 4^{\text {th }}$ were married, Muslims were dominating and belonged to socio economic class III and IV. Though they may have to purchase medicines from outsides almost all had trust in government health facility hence visiting this center. According to their perceptions about their own health, only $34 \%$ thought of healthy currently. More than $3 / 4^{\text {th }}$ preferred government hospital in case of major illness while during minor illness home remedies due to trust in the health care services offered by them.

Conclusions: It is essential to carry out health awareness measures so as to reduce acute respiratory tract illness in that area and reduce time gap between symptom and health care services availed.
\end{abstract}

Key words: Health seeking behavior, Determinants, Urban health center

\section{INTRODUCTION}

According to WHO, health is a state of complete physical, mental and social well-being and not merely the absence of disease or infirmity. ${ }^{1}$ It is not a static condition, constant change and adaptation to stress result in homeostasis. When an individual makes a decision in relation to health, he/she weighs up the potential risks or benefits of a particular behaviour. But they do so in a way that is mediated by their immediate practical environment, their social rootedness, socioeconomic status and their whole outlook on life more generally which may or may not apparently be relevant to an act of health seeking behaviour. ${ }^{2}$
Health seeking behaviour is drawing out the factors which enable or prevent people from making 'healthy choices', in either their lifestyle behaviours or their use of medical care and treatment. Thus, health care seeking behaviour is conceptualized as a 'sequence of remedial actions' taken to correct 'perceived ill-health' ${ }^{3}$

Health seeking behaviour is an important factor in health management, but this is often ignored while providing health facilities to people. As a result, facilities for providing health care do not get the desired acceptance of the community, and are therefore rendered unsuccessful. Not only the decision makers, but health care providers should also understand the health seeking behaviour of the community along with their health seeking practices 
and their perception regarding the service delivery. This becomes especially relevant among under-privileged populations like urban slums, tribal populations. ${ }^{4}$

In Mumbai, more than $50 \%(54.05 \%)$ population lives in slum areas. ${ }^{5}$ Urban slum at Dharavi, Mumbai is one of the biggest slums of the world sheltering above 6 lakh population which consists of area-wise pockets of various groups differing in religion, castes, customs and beliefs, socioeconomic condition, housing etc. ${ }^{6}$ Urban Health Center, Dharavi is one of the center working for slum population of Dharavi, Mumbai. It was established in 1981 serving the population for last 34 years and starting from the mobile van.

In early seventies, the grass root level workers waded through marshy places to reach out to door steps of the slum dwellers. In 1981, three rooms were allotted to Department of Community Medicine for offering General outpatient services at UHC.

This center was upgraded to indoor facilities of 100 beds in 1988. This center has alliance with various NonGovernmental Organizations. Now it is well established center having various outpatient services. This center follows following Principles promotive, preventive, curative, rehabilitative, training and research.

Aim of the study was to study health seeking behavior and its determinants among attendees at urban health center Dharavi, Mumbai and objectives of the study was to understand the health seeking behavior among attendees at urban health center, Dharavi and to study the factors affecting their health seeking behaviour and to find out their suggestions for better health care delivery.

\section{METHODS}

This cross sectional study was conducted among attendees of General OPD at Urban Health Center, Dharavi, Mumbai. They were selected by systemic random method. After taking their valid informed consent, they were included in the study. Duration of the study was January 2015 to August 2015.

\section{Sample size}

$\mathrm{n}=\mathrm{Z}_{1-\mathrm{a} / 2} \mathrm{p}(1-\mathrm{p}) / \mathrm{d}^{2} \mathrm{P}$ was taken as $50 \%$ which will give higher value of minimum sample size

$\mathrm{d}=$ five percentage points on either side of $\mathrm{p}$

$\mathrm{n}=384$ which was rounded to nearest number 400 for overall prevalence. Thus, the sample size was $400^{7}$

\section{Sampling method}

Individuals visiting to UHC were selected by systematic random method.

\section{Data collection}

Daily there were nearly 100 patients visiting the respective OPD. Every $10^{\text {th }}$ person visiting to adult OPD was selected. Thus data was collected for five days a week for two months.

\section{Inclusion criteria}

- $\quad$ Adults (>19yrs age) attending and residing near Urban Health Centre Dharavi, Mumbai.

\section{Exclusion criteria}

- Individuals not willing to take part in the study

- Very sick individuals.

Study tools included Pre- designed, pre-tested, semi structured questionnaire and had 4 parts.

Part 1: Included their Socio demographic data.

Part 2: included perception about their own health for last 1 year and common illnesses in their area.

Part 3: Utilisation of health services such as utilisation pattern for major and minor illness- mode, time and source to access health care facility and availability of type of health facilities, information about their past illness, gap between $1^{\text {st }}$ symptom and visit to health care facility - reasons.

Part 4: included community needs based on expenses made at govt. hospitals for medicines, investigations and their views about improving health services for better future health care delivery.

\section{Operational definitions}

Health-care-seeking behaviour was defined as: formal, when professional help was sought from health care services and/or health care providers (physicians, psychologists); informal relational, when help was sought from members of his / her social network (parents, friends, teachers, trusted persons. ${ }^{8}$

Under Section-3 of the Slum Area Improvement and Clearance Act, 1956, slums have been defined as mainly those residential areas where dwellings are in any respect unfit for human habitation by reasons of dilapidation, overcrowding, faulty arrangements and designs of such buildings, narrowness or faulty arrangement of streets, lack of ventilation, light, sanitation facilities or any combination of these factors which are detrimental to safety, health and morals. ${ }^{9}$

As per UN Habitat a slum is characterized by lack of durable housing, insufficient living area, lack of access to clean water, inadequate sanitation and insecure tenure. ${ }^{9}$ 


\section{RESULTS}

Table 1: Socio-demographic profile of the study population.

\begin{tabular}{|c|c|c|}
\hline Socio-demographic profile & Frequency & Percentage \\
\hline \multicolumn{3}{|l|}{ Age (in years) } \\
\hline$<20$ & 46 & 11.5 \\
\hline $21-30$ & 118 & 29.5 \\
\hline $31-40$ & 101 & 25.25 \\
\hline $41-50$ & 78 & 19.5 \\
\hline $51-60$ & 37 & 9.25 \\
\hline$>60$ & 20 & 5 \\
\hline \multicolumn{3}{|l|}{ Sex } \\
\hline Male & 207 & 51.75 \\
\hline Female & 193 & 48.25 \\
\hline \multicolumn{3}{|l|}{ Religion } \\
\hline Muslim & 247 & 61.75 \\
\hline Hindu & 131 & 32.75 \\
\hline Christian & 13 & 3.25 \\
\hline Others & 9 & 2.25 \\
\hline \multicolumn{3}{|l|}{ Marital status } \\
\hline Married & 310 & 77.5 \\
\hline Unmarried & 70 & 17.5 \\
\hline Divorcee & 6 & 1.5 \\
\hline Widow/widower & 14 & 3.5 \\
\hline \multicolumn{3}{|l|}{ Education } \\
\hline Illiteracy & 100 & 25 \\
\hline Primary & 72 & 18 \\
\hline Secondary & 158 & 39.5 \\
\hline Higher secondary & 50 & 12.5 \\
\hline Graduate & 20 & 5 \\
\hline \multicolumn{3}{|l|}{ Type of family } \\
\hline Nuclear & 272 & 68 \\
\hline Joint & 110 & 27.5 \\
\hline Extended Joint & 18 & 4.5 \\
\hline \multicolumn{3}{|l|}{ Socioeconomic class } \\
\hline Class I & 16 & 4 \\
\hline Class II & 82 & 20.5 \\
\hline Class III & 113 & 28.25 \\
\hline Class IV & 154 & 38 \\
\hline Class V & 35 & 8.75 \\
\hline \multicolumn{3}{|l|}{ Residing since } \\
\hline $0-5$ years & 147 & 36.75 \\
\hline 5- 10 years & 104 & 26 \\
\hline 10- 15 years & 57 & 14.25 \\
\hline$>15$ years & 96 & 24 \\
\hline Total & 400 & 100 \\
\hline
\end{tabular}

Socio-demographic profile of the study population was shown in Table 1. The most common age group visited to Urban Health Centre was 21-30 years 118 (29.5\%) followed by 31-40 years consisting of 101 attendees $(25.25 \%)$. The mean age was $36.44(+/-14.10 \mathrm{SD})$ years.
Table 2: Distribution of attendees according to utilization of health services.

\begin{tabular}{|c|c|c|}
\hline Category & Frequency & Percentage \\
\hline \multicolumn{3}{|c|}{ Source of availing health facility } \\
\hline Government & 342 & 85.5 \\
\hline Private & 56 & 14 \\
\hline Both (Govt. \& Pvt.) & 12 & 3 \\
\hline \multicolumn{3}{|c|}{ Way to reach health facility } \\
\hline Walking & 351 & 87.75 \\
\hline Bicycle & 9 & 2.25 \\
\hline $\begin{array}{l}\text { Transport services } \\
\text { (Bus, taxi, train) }\end{array}$ & 31 & 7.75 \\
\hline Own vehicle & 9 & 2.25 \\
\hline \multicolumn{3}{|c|}{ Time taken to reach the nearest health facility } \\
\hline$<15$ min & 309 & 77.25 \\
\hline $15-30 \mathrm{~min}$ & 82 & 20.5 \\
\hline $30 \mathrm{~min}-60 \mathrm{~min}$ & 7 & 1.75 \\
\hline$>60 \min$ & 2 & 0.5 \\
\hline \multicolumn{3}{|c|}{$\begin{array}{l}\text { Time gap between visit to the health facility and the } \\
\text { onset of symptoms }\end{array}$} \\
\hline On the same day & 17 & 4.25 \\
\hline 1 day & 120 & 30 \\
\hline 2 days & 100 & 25 \\
\hline 3 days & 68 & 17 \\
\hline >3days & 95 & 23.75 \\
\hline \multicolumn{3}{|c|}{$\begin{array}{l}\text { Money spent at Govt. health facilities for purchase of } \\
\text { the medicine }\end{array}$} \\
\hline Free of cost & 184 & 46 \\
\hline$<100$ Rs. & 109 & 27.25 \\
\hline 100 - 500 Rs. & 123 & 30.75 \\
\hline $500-1000$ Rs. & 21 & 5.25 \\
\hline$>1000$ Rs. & 3 & 0.75 \\
\hline \multicolumn{3}{|c|}{$\begin{array}{l}\text { Money spent at Govt. health facilities for } \\
\text { investigations }\end{array}$} \\
\hline Free of cost & 205 & 51.25 \\
\hline$<100$ Rs. & 69 & 17.25 \\
\hline 100 - 500 Rs. & 93 & 23.25 \\
\hline $500-1000$ Rs. & 31 & 7.75 \\
\hline$>1000$ Rs. & 2 & 0.5 \\
\hline \multicolumn{3}{|c|}{ Reason to choose particular health facility } \\
\hline $\begin{array}{l}\text { Trust over the } \\
\text { provider of the } \\
\text { facility }\end{array}$ & 126 & 31.5 \\
\hline Near to home & 80 & 20 \\
\hline Affordable & 70 & 1.75 \\
\hline $\begin{array}{l}\text { Staff availability \& } \\
\text { co-operation }\end{array}$ & 51 & 12.75 \\
\hline $\begin{array}{l}\text { Good quality } \\
\text { treatment }\end{array}$ & 41 & 10.25 \\
\hline $\begin{array}{l}\text { Less time } \\
\text { consuming }\end{array}$ & 32 & 8 \\
\hline
\end{tabular}

The distribution of sex was almost equal among the study participants. The dominance of religion in the study subjects was in the following sequence of Muslim 247 (61.75\%), Hindu 131 (32.75\%), and Christian 13 
$(3.25 \%)$. Out of total study subjects $3 / 4^{\text {th }}$ were married, $1 / 4^{\text {th }}$ being illiterate and $68 \%$ had nuclear families. According to B.G. Prasad classification, maximum (38\%) attendees belonged to class IV and $113(28 \%)$ to class III of socioeconomic status. $36.75 \%$ attendees were residing in that area since last 5 years while $26 \%$ for 5 to 10 years.

Table 3: Perception about their own health currently and for last 1 year.

\begin{tabular}{|llllll|}
\hline Perception & Likert's Scale & & \\
\hline & Poor & Average & Good & Better & Excellent \\
\hline $\begin{array}{l}\text { Current health status of the attendees as } \\
\text { rated by themselves }\end{array}$ & $23(5.75 \%)$ & $174(43.5 \%)$ & $137(34.25 \%)$ & $63(15.75 \%)$ & $3(0.75 \%)$ \\
\hline $\begin{array}{l}\text { Past 1 year Health status of the attendees as } \\
\text { rated by themselves }\end{array}$ & $24(6 \%)$ & $146(36.5 \%)$ & $177(44.25 \%)$ & $49(12.25 \%)$ & $4(1 \%)$ \\
\hline
\end{tabular}

Distribution of attendees according to utilization of health services was shown in Table 2. Majority $85.5 \%$ most commonly availed Government health facilities for their illness. Almost all attendees, walked down to reach nearest health facility and $77.25 \%$ took less than 15 minutes to reach the nearest health facility. Only $4 \%$ of the attendees were visited the health facility on the same day of beginning of symptoms.

Table 4: Perception about common acute and chronic illnesses in their area.

Perception of most common acute illness in the area

\begin{tabular}{|c|c|c|}
\hline ARI & 152 & 38 \\
\hline AFI/ Malaria/ Dengue & 119 & 29.75 \\
\hline Skin diseases & 47 & 11.75 \\
\hline Age & 40 & 10 \\
\hline Don't know & 42 & 10.5 \\
\hline \multicolumn{3}{|c|}{$\begin{array}{l}\text { Perception of most common chronic illness in the } \\
\text { area }\end{array}$} \\
\hline Tuberculosis & 123 & 30.75 \\
\hline Hypertension & 94 & 23.5 \\
\hline Diabetes Mellitus & 90 & 22.5 \\
\hline Don't know & 61 & 15.25 \\
\hline leprosy & 17 & 4.25 \\
\hline Others & 15 & 3.75 \\
\hline
\end{tabular}

Though medicines and investigations are free and at low cost in government, still half of the attendees had to pay for the medicines from outside and investigations. This was due to limited supply of medicines. In government set up. In case of choosing a particular health facility, the trust was the most common and important reason to choose in $31 \%$ of attendees.

Perception about their own health currently and for last 1 year was shown in Table 3. The perception of the participants about their current and last one year health was asked and they rated their own health on the basis of Likert's scale. Only 34\% of them thought that they had good health currently, while $44 \%$ thought of good health in the past 1 year.
Perception about common acute and chronic illnesses in their area was shown in Table 4. Most common acute illness in their area perceived by them was acute respiratory tract illness followed by acute febrile illness, malaria, and dengue. They perceived Tuberculosis, hypertension, diabetes to be chronic illnesses common in their area.

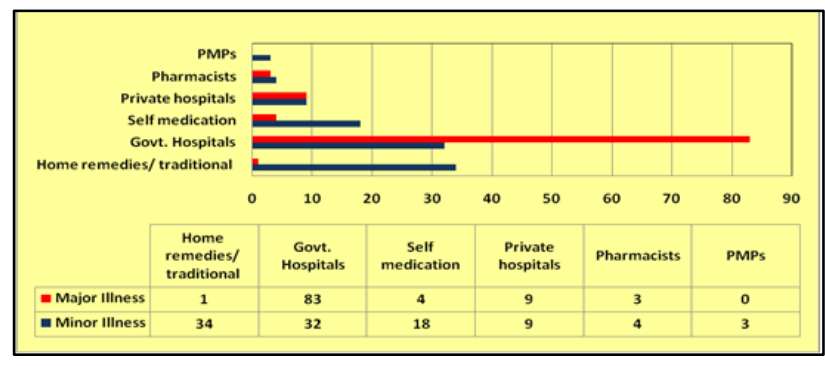

Figure 1: Distribution of health facility options chosen in case of major and minor illness.

Distribution of health facility options chosen in case of major and minor illness was shown in Figure 1. About 83 $\%$ of the attendees preferred government hospitals in case of major illness while $34 \%$ preferred home remedies and $32 \%$ desired government hospitals for minor illnesses.

Some of the suggestions by the participants were- all investigations to be available at the center, improved cleanliness and all medicines should be available always, emergency services should be started at the center.

\section{DISCUSSION}

According to Rose Ann Dominic et al.10 28.8\% were having positive health seeking behavior towards government health care facilities. Mean age was 43.5\%, $58.8 \%$ of them were female. $76.5 \%$ of samples belonged to Hindu religion. There was a significant association between health seeking behavior and demographic variables such as age, education and family income. Majority of the samples were utilizing the private health care facilities during their period of health problems. For general health problems, majority of the sample never utilize the government health care facilities. $41.92 \%$ 
sample wished to go always to government health facilities for seeking care for chronic health problems. A study conducted by Lakhwinder P Singh and Shiv D Gupta to assess the health seeking behavior and health care services in Rajasthan. ${ }^{4}$ They found that the problems being faced by the people while utilizing government health care services were inaccessibility due to lack of transportation, unsympathetic attitude of the staff dispensing the health services, and shortage or nonavailability of medicines. While in current study mean age was 36.44(+/- 14.10 SD) years, attendees were equal among both sexes. The area where this study was conducted was dominated by Muslim community. There was positive health seeking behavior to access the government health facility in major illness. This is due to their trust among the staff and services provided by this center which is situated in the middle of urban slum area. Tejas Shah et al. ${ }^{11}$ Ahmedabad found significant difference in place for treatment of acute illness from faith healers. More rural people $(29.2 \%)$ took treatment from faith healers than urban $(22.8 \%)$. Injury $(37.4 \%)$ was important cause for hospitalization in rural area while infection was important cause for hospitalization in urban area (39.3\%). Vimala Thomas et al, Hyderabad found majority of the elderly went to private clinics for their treatment. ${ }^{12}$

Marinka van der Hoeven explored possible differences in health care seeking behaviour among a rural and urban African population and found that most of the participants in both urban and rural communities rated the impact of HIV or AIDS as large and indicated that its effect was worse than that of any other disease. ${ }^{13}$ This may be due to high prevalence of HIV/AIDS in their country. The current study found that most common acute illness in the area were this study was conducted as perceived by participants was acute respiratory tract illness followed by acute febrile illness, malaria, and dengue which may need hospitalization. They perceived Tuberculosis, hypertension, diabetes to be chronic illnesses common in their area.

Saswat kumar Pradhan Odisha tribal study found that around $34.20 \%$ sample households visits government hospitals/ doctors during any illness, $29.5 \%$ rely on quack, $18.5 \%$ visit gunia (priest), $13.7 \%$ visit to village medicine men, only $4.1 \%$ visit private clinic due to low socio economic status. ${ }^{2}$ The study conducted by Pradeep Agrawal et al. ${ }^{14}$ In rural community of Dehradun that majority of the respondents $(76.9 \%)$ had responded in favour of quacks and/or spiritual, traditional healers. On the contrary, majority of symptomatic $(55 \%)$ said that they would like to be treated by a qualified allopathic doctor. Bandana Sachdev conducted study among Nomad Tribal populations of Rajasthan described that though $61 \%$ were aware but not availing government aided health facilities while Syed Azizur Rahman observed traditional healers which are still very popular among the tribal population in Bangladesh. ${ }^{15,16}$
The urban health center in consideration for this study, serves the urban slums having a mixture of people hailing from rural and tribal parts of the nearby states. Even though the selected area has various healthcare services offered by several providers, the participants of the study preferred the services provided by the government health center due to faith in the services provided and proximity to their place (within walking distance).

\section{CONCLUSION}

This cross sectional study was conducted among 400 attendees of General OPD at Urban Health Center, Dharavi. The mean age was 36.44(+/- 14.10 SD) years. Both sexes were attending to utilize services, More than $3 / 4^{\text {th }}$ were married, Muslims were dominating and belonged to socio economic class III and IV. Though they may have to purchase medicines from outsides almost all had trust in government health facility hence visiting this center. According to their perceptions about their own health, only $34 \%$ thought of healthy currently. More than 3/4th preferred government hospital in case of major illness while during minor illness home remedies due to trust in the health care services offered by them. The time gap between the symptoms and seeking health care services was $\geq 2$ days, which may cause delay in treatment and cure too. According to their perceptions acute respiratory tract illness, acute febrile illness, malaria, and dengue were commonest acute illness which is due to overcrowding in that area. Participants' valuable suggestions shall improve health care services if implemented. There is urgent need to address the reasons behind their perceptions regarding their current health status being average and poor health. Also, vigorous awareness should be conducted so that there is very less time gap between symptom and health care services availed. It is essential to carry out health awareness measures so as to reduce acute respiratory tract illness in the area.

\section{Funding: No funding sources Conflict of interest: None declared \\ Ethical approval: The study was approved by the Institutional Ethics Committee}

\section{REFERENCES}

1. Park K. Preventive and Social Medicine. Bhanot Publishers, $22^{\text {nd }}$ ed. 2013:14-5.

2. Pradhan SK. Health and health seeking behaviour among the tribals: a case study in Sundargarh district of Odisha, Department of Humanities and Social Sciences, National Institute of Technology, Rourkela, Odisha. 2013.

3. MacKian S. A review of health seeking behaviour: problems and prospect. HSD/WP/05/03.

4. Singh LP, Gupta SD. Health seeking behaviour and healthcare services in Rajasthan, India: a tribal community's perspective. Institute of Health Management Research, Jaipur, IIHMR. 
5. Slums in India. A statistical Compendium, 2011. Government of India. Mministry of Housing and Urban Poverty Alleviation. National Buildings Organisation. $147 . \quad$ Available at:http://nbo.nic.in/Images/PDF/Slum_in_india_201 1_english_book_23_May_12.pdf. Accessed on 17 March 2016.

6. Borgenproject.org/ 5 largest slums of the world. Available at: http://borgenproject.org/5-largestslums-world/. Accessed on 17 March 2016.

7. Adequacy of Sample size in Health studies' book by Lemeshow and Lwanga 1990, World Health Organisation, 1990.

8. Kahi HE, AbiRizket GY. Health-care-seeking behaviour among students of Lebanon university, Eastern Mediterranean Health Journal. 2012;18(6):598-606.

9. Census of India 2011. Primary census abstract for slum, 2011. Office of the Registrar General and Census Commissioner, India New Delhi, 30-09$2013 . \quad$ Available at:http://www.censusindia.gov.in/2011.Documents/ Slum-26-09-13.pdf Accessed on 17 March 2016.

10. Dominic RA, Shashidhara YN, Nayak MG. Nitte University Journal of Health Science. 2013;3(3):7782.

11. Shah T, Patel M, Shah V. Health care seeking behaviour of urban and rural community in Ahmedabad district. International Journal of
Medical Science and Public Health. 2013;2(4):90911.

12. Thomas V, Lavanya KM, Muraleedhar. Morbidity profile and health seeking behaviour of the elderly in urban slums of Hyderabad, Andhra Pradesh, India - a cross sectional study. IJCRR. 2012;4(19):174-80.

13. der Hoeven MV, Kruger A, der Hoeven MG. Differences in health care seeking behaviour between rural and urban communities in South Africa. Int J Equity Health. 2012;11:31.

14. Aggarwal P, Kandpal SD, Negi KS, Gupta P. Health seeking behaviour for RTIs/ STIs: study of a rural community in Dehradun. Health and population: perspectives and issues. 2009;32(2):66-72.

15. Sachdev B. Perspectives on health, health needs and health care services among select nomad tribal populations of Rajasthan, India. Antrocom Online. J Anthropol. 2012;8(1):73-81.

16. Rahman SA, Kielmann T, McPake B, Normand C. Healthcare-seeking behaviour among the tribal people of Bangladesh: can the current health system really meet their needs? J Health Popul Nutr. 2012;30(3):353-65.

Cite this article as: Patil SP, Parbhankar SS, BansodeGokhe SS, Shelke PS, Singh RD. Study of health seeking behavior and its determinants among attendees of urban health center, Dharavi, Mumbai, India. Int J Community Med Public Health 2016;3:1856-61. 